\title{
ERECTOR SPINAE AND SCOLIOSIS IN A POPULATION WITH CEREBRAL PALSY: A PRELIMINARY STUDY
}

\author{
ERECTOR DA ESPINHA E ESCOLIOSE EM UMA POPULAÇÃO COM PARALISIA CEREBRAL: \\ ESTUDO PRELIMINAR \\ MÚSCULO ERECTOR DE LA COLUMNA Y ESCOLIOSIS EN UNA POBLACIÓN CON \\ PARÁLISIS CEREBRAL: ESTUDIO PRELIMINAR
}

Osama J. Ali-Morell' , Félix Zurita-Ortega², Berenice Fernández-Estévez¹, Beatriz Padilla-Obispo³, Roberto Martínez-Porcel ${ }^{1}$

1. PhysicalTherapy Service, Fundación Purísima Concepción de Granada. Spain.

2. Universidad de Granada. Spain.

3. Colegio Amor de Dios de Granada. Spain.

\begin{abstract}
Objective: To verify the relation of muscular response to the vestibular stimulation of the erector spinae, specifically longissimus thoracis and iliocostalis lumborum, with the origin of scoliosis in a population of individuals with level V cerebral palsy of the Gross Motor Function Classification System (GMFCS). Methods: Cross-sectional study of 12 individuals aged between four and 14 years. The muscular activity of the longissimus thoracis and iliocostalis lumborum was recorded by electromyography in the presence of anteroposterior and lateral imbalances, comparing it with that obtained in sitting position without imbalances. Scoliosis was assessed by radiological study following Cobb method. Results: Statistically significant differences were found between correct responses of both muscles to anteroposterior imbalances and absence of right thoracolumbar scoliosis $(p=0.005 ; p=0.028)$, left thoracic scoliosis $(p=0.005 ; p=0.046)$ and right lumbar scoliosis $(p=0.005 ; p=0.046)$. Conclusions: The symmetry of muscular responses to anteroposterior imbalances, both of longissimus thoracis and iliocostalis lumborum, seems to be one of the factors that prevent the development of spine deviations in this population. Level of evidence: IV. Type of Study: Case series
\end{abstract}

Keywords: Cerebral palsy; Scoliosis; Muscles; Electromyography.

RESUMO

Objetivo: Avaliar a relação da resposta muscular à estimulação vestibular do eretor da espinha, específicamente longuíssimo do tórax e iliocostal lombar, com a origen da escoliose em uma população de individuos com paralisia cerebral pertencente ao grupo V da sistema classificação da função motora grossa (GMFCS). Métodos: Estudo transversal de 12 indivíduos com idade entre quatro e 14 anos. A atividade muscular contra desequilibrios anteroposterior e laterais do longuíssimo do tórax e iliocostal lombar foi gravado em comparação com a obtida sem desestabilição na posição sentada. Escoliose radiografias foram avalaidas utilizando o método de Cobb. Resultados: Foram observados diferençãs estatisticamente significativas entre as respostas corretas de ambos músculos contra desequilíbrios anteroposteriores e falta de escoliose toraco-lombar direita ( $p=0.005 ; p=0.028)$, torácica esquerda $(p=0.005 ; p=0.046)$ e lombar direita ( $p=0.005$; $p=0.046)$. Conclusões: A simetría das respostas do músculo contra desequilíbrios ântero-posterior, tanto longuissimo do tórax como iliocostal lombar, parece ser um dos factores que impedem a ocorrência de desvíos da coluna vertebral em nesta população. Nivel de Evidência: IV. Tipo de Estudos: Série de Casos

Descritores: Paralisia cerebral; Escoliose; Músculos; Eletromiografía.

\section{RESUMEN}

Objetivo: Comprobar la relación de la respuesta muscular ante la estimulación vestibular del músculo erector de la columna, concretamente músculo longísimo torácico e iliocostal lumbar, con el origen de la escoliosis en una población de individuos con parálisis cerebral de nivel V de la Gross Motor Function Classification System (GMFCS). Métodos: Estudio transversal de 12 individuos de edades comprendidas entre los cuatro y los 14 años. Se registró mediante electromiógrafo la actividad muscular del longísimo torácico e iliocostal lumbar ante desequilibrios anteroposteriores y laterales, comparándola con la obtenida en sedestación sin desestabilizaciones. Las escoliosis se valoraron mediante estudio radiológico siguiendo el método de Cobb. Resultados: Se observan diferencias estadísticamente significativas entre respuestas correctas de ambos músculos ante los desequilibrios anteroposteriores y ausencia de escoliosis toracolumbar derecha $(p=0,005$; $p=0,028)$, dorsal izquierda $(p=0,005 ; p=0,046)$ y lumbar derecha $(p=0,005 ; p=0,046)$. Conclusiones: La simetría de las respuestas musculares ante los desequilibrios anteroposteriores, tanto del músculo longísimo torácico como del iliocostal lumbar, parece ser uno de los factores que evitan la aparición de las desviaciones del raquis en esta población. Nivel de evidencia: IV.Tipo de Estudo: Serie de Casos.

Descriptores: Parálisis cerebral; Escoliosis; Músculos; Electromiografía. 


\section{INTRODUCTION}

Cerebral palsy (CP) describes a group of encephalopathies that occurs in childhood and, in many cases, causes secondary musculoskeletal changes. Deviations of the spine are common, becoming structured (scoliosis) in $25 \%$ of individuals. ${ }^{1}$

Although patterns of scoliosis have been described in relation to pelvic obliquity and hip dislocation ${ }^{2}$ and postural asymmetry have been associated with scoliosis, ${ }^{3}$ the mechanism that causes development and increase of the curvature over time is not completely understood. Thus, in spite of orthopedic and physical therapy measures, most of these cases end up being treated surgically.

That is why there has been such broad diversification in research, following other lines distinct from those traditionally considered. Thus, some studies have associated both fetal postures and those maintained during the first years of life ${ }^{4}$ with spinal deviations, noting the importance of asymmetries and postural preferences in the development and structuring of postural changes, but never explaining the underlying neurological mechanisms that produce them.

On the other hand, several authors agree in reporting the severity of the scoliosis with the lowest levels of autonomy, ${ }^{5,6}$ establishing therefore relationships with alterations in muscular control. ${ }^{7}$

In this sense, Domagalska and Szopa ${ }^{8}$ describe, in individuals with unilateral CPs that present scoliosis, postural patterns different from those observed in patients with mild scolioses.

Therefore, there is a specific line of research focused on postural control and the postural reflex mechanism, noting vestibular implications in the population with cerebral palsy also observed in patients with idiopathic scolioses. ${ }^{9}$ Specifically in CP, the vestibulocervical reflexes (VCR) have been associated both with gross motor function ${ }^{10}$ and scolioses. ${ }^{5}$ However, these studies, in addition to treating spinal deviations in a global manner and without specifying directions, have been limited to the responses of the cervical musculature, such that an evaluation of the responses of the erector spinae, both as the main extensor of the thoracolumbar region ${ }^{11}$ and as the effector of the vestibulospinal reflexes (VSR) at the level of the trunk, ${ }^{12}$ are left pending

Thus we can understand that the patients with $\mathrm{CP}$ and who have greater limitation of mobility (GMFCS level V) ${ }^{13}$ are the most affected and with greater severity due to the appearance of lateralizations and vertebral rotations. However, the mechanisms involved are unknown, and it is impossible to predict the specific deviations to be expected and their evolution for each patient. Moreover, due to the fact that this group has shown conservative treatment to be insufficient, ${ }^{14,15}$ we consider it necessary to enter this field to know exactly, and thus correctly address both care and prevention from a global point of view (orthopedic, surgical, neurological, and physiotherapeutic).

For these reasons, and following a line of investigation related to postural reflexes and association with motor function and scoliosis in previous studies, ${ }^{5,10}$ the objective of this study was established:

- To define the implications of the response of the erector spinae, specifically the longissimus thoracis (LT) and lumbar iliocostalis (IC), in the origin and/or development of scolioses in a population of patients with CP GMFCS level V.

\section{METHODS}

This is a descriptive, observational, cross-sectional study. The sample was selected from the student body of the Purísima Concepción Special Education Center of Granada, the inclusion criteria being a diagnosis of infantile cerebral palsy GMFCS level V. The exclusion criteria consisted of having undergone corrective surgery for scoliosis, belonging to a different GMFCS level, or having a diagnosis different from that specified by the inclusion criteria.

Consecutive sampling was performed so that all the patients who met the inclusion criteria during the data collection period were selected, ultimately yielding a sample of 12 patients with $\mathrm{CP}$, ranging from four to 14 years of age, who were treated regularly at the Physical Therapy Unit of the Center.

Protection of the people: The authors declare that the procedures followed comply with the Declaration of Helsinki of the World
Health Organization and are in accordance with the standards of the Hermanas Hospitalarias Institutional Review Board.

Confidentiality and informed consent: The authors declare that they followed the workplace protocols for access to and publication of patient data and that all the patients included in the study received sufficient information and gave their informed consent in writing for participation in the study. This document is in the possession of the corresponding author.

Privacy: The authors declare that patient data do not appear in this article. In the study, the independent variable was defined as the muscular activity of the erector spinae in the presence of lateral and anteroposterior imbalances, while alterations of the spine constituted the dependent variables.

Thus, the variables were established as:

- Activity of the longissimus thoracis right (RLT) and left (LLT) muscles with and without lateral imbalances.

- Activity of the RLT and LLT with and without anteroposterior imbalances.

- Activity of the iliocostalis lumborum right (RIC) and left (LIC) muscles with and without lateral imbalances.

- Activity of the RIC and LIC with and without anteroposterior imbalances.

- Type of scoliosis.

Surface electromyography was used to evaluate the bilateral muscular activity of LT and IC, as was done in previous studies of this population. ${ }^{10,16}$ The apparatus used was the Myomed $\AA 632 \mathrm{VX}$, with a sensitivity of $0.5-10,000$ microvolts, a bandwidth of $5-1,500 \mathrm{~Hz}$, and digital filter. It was used in combination with a data transmission unit for further processing (Myocombox ${ }^{\circledR}$ ). Self-adhesive, $20 \mathrm{~mm}$ diameter electrodes (EN-trode $\AA$ ) were used.

The bipolar method was used to measure the muscular activity of the thoracolumbar extensor group (LT and IC) with an electrode more for reference, following the guidelines of the SENIAM Project ${ }^{17}$ for both muscle groups.

The measurements were taken based on the methodology followed in previous studies. ${ }^{12}$

The contraction of the right and left iliocostalis lumborum and longissimus thoracis groups was recorded for one minute with the patient in a sitting position with their legs in the air and with an adult supporting both shoulders to record it causing lateral and anteroposterior imbalances at fixed speed and inclination ( $45^{\circ}$ in one second).

The average values of contraction in a sitting position without imbalance (S), in a sitting position with lateral imbalances (Lat), and in a sitting position with anteroposterior imbalances (AP) were recorded.

Subsequently, the average Lat and AP contraction values were expressed in proportion to $\mathrm{S}$ :

- [Average contraction in Lat/Average contraction in S] ( $\mu$ Lat)

- [Average contraction in AP/Average contraction in S] ( $\mathrm{AP}$ )

Finally, both $\mu$ Lat and $\mu \mathrm{AP}$ were divided into two groups:

- Correct response: when the result of the ratio between contraction with imbalances and contraction without imbalance for the musculature being assessed is equal to or greater than one.

- Insufficient response: when the result of the ratio between contraction with imbalances and contraction without imbalance for the musculature being assessed is less than one.

Radiological exams were used to determine the type of scoliosis, measured using the Cobb method, the reliability of which has been proven ${ }^{18}$ both in quantifying the degree and indicating the vertebral limits.

The radiographs were performed in decubitus and traction.

The types of scoliosis were classified in relation to location, according to the standards of the Scoliosis Research Society (thoracic: the apex of the curve between T2 and the T11/T12 intervertebral disc; thoracolumbar: the apex of the curve between T12 and L1; lumbar: the apex of the curve between discs L1/L2 and L4).

They were also distributed by direction (left or right) using the convexity of the curve as a reference.

Finally, each patient was classified by scoliosis type according to the criteria defined by Lenke. ${ }^{19}$ 
Due to limitations in the measurement of curves of less than 10 degrees ${ }^{20}$ and taking the Scoliosis Research Society and National Scoliosis Foundation guidelines into account, only the curves that exceeded this measurement using the Cobb method were included.

This study was conducted according to the protocols established in the Fundación Purísima Concepción Center, requesting informed consent by means of an authorization model approved by the Institutional Review Board of the Hermanas Hospitalarias (representative FPC Granada 03/2014).

The investigators were responsible for collecting the data and confirming the correct administration of the tests. The collection was accomplished without any type of abnormality.

Statistical analysis was conducted using SPSS 20.0 for Windows. The participation index was $100 \%$. First, descriptive data analysis techniques were used to determine frequencies and percentages. To check to what extent some type of relationship was produced, contingency tables and Pearson's chi square test were used.

\section{RESULTS}

Twelve people with CP, aged from four to 14 years old (mean 9.3 years, SD 3.57), participated in the study, 58.3\% $(n=7)$ of whom were girls and $41.7 \%(n=5)$ of whom were boys. Spastic quadriplegia was present in $83.3 \%(n=10)$ and dyskinetic quadriplegia in the remaining $16.7 \%(n=2)$.

In terms of etiology, $41.7 \%(n=5)$ had hypoxic ischemic encephalopathy, $25 \%(n=3)$ acute fetal distress, $16.7 \%(n=2)$ cytomegalovirus, and $16.7 \%(n=2)$ microcephaly.

The classification of the patients by location and type of scoliosis is presented in Table 1 .

As regards the frequencies and percentages of the types of spinal deviations (Table 2), no cases of left thoracic or right lumbar scoliosis were detected, and right and left thoracolumbar scolioses made up the highest percentages.

In terms of lateral imbalances (Table 3), only the muscle response of the bilateral LT in right thoracolumbar scoliosis showed a statistically significant difference $(p=0.028)$.

We confirmed that, in cases in which scoliosis was not present, the highest percentages referred to symmetrical responses: $37.5 \%$ $(n=3)$ had an insufficient response for both right and left LT and $50 \%$ $(n=4)$ had a correct response for right and left LT.

As for the anteroposterior imbalances for IC (Table 4), we observed statistically significant differences for the presence of left thoracolumbar scoliosis $(p=0.014)$ and for the absence of right thoracolumbar scoliosis $(p=0.028)$, left thoracic scoliosis $(p=0.046)$, and right lumbar scoliosis $(p=0.046)$.

Table 1. Classification of the patients according to the location and type of scoliosis (Lenke classification ${ }^{19}$ ).

\begin{tabular}{c|c|c|c}
\hline & Type of curve & Cobb Angle & Lenke Classification \\
\hline 1 & Left thoracolumbar & $40^{\circ}$ & $5 \mathrm{CN}$ \\
\hline 2 & Right thoracolumbar & $55^{\circ}$ & $5 \mathrm{CN}$ \\
\hline 3 & Left thoracolumbar & $28^{\circ}$ & $5 \mathrm{~B}+$ \\
\hline 4 & Left thoracolumbar & $30^{\circ}$ & $5 \mathrm{~B}+$ \\
\hline 5 & Left thoracolumbar & $42^{\circ}$ & $5 \mathrm{C}+$ \\
\hline 6 & Right thoracolumbar & $38^{\circ}$ & $5 \mathrm{C}-$ \\
\hline 7 & Left thoracolumbar & $28^{\circ}$ & $5 \mathrm{~B}+$ \\
\hline 8 & Right thoracolumbar & $25^{\circ}$ & $5 \mathrm{BN}$ \\
\hline \multirow{2}{*}{9} & Right thoracic & $32^{\circ}$ & \multirow{2}{*}{$3 \mathrm{AN}$} \\
\cline { 2 - 3 } & Left lumbar & $26^{\circ}$ & \\
\hline 10 & Right thoracolumbar & 30 & $5 \mathrm{BN}$ \\
\hline 11 & Right thoracic & $35^{\circ}$ & 1A+ \\
\hline \multirow{2}{*}{12} & Right thoracic & $40^{\circ}$ & \multirow{2}{*}{$6 \mathrm{C}-$} \\
\cline { 2 - 3 } & Left thoracolumbar & $56^{\circ}$ & \\
\hline
\end{tabular}

Cobb angle measurement ${ }^{18}$ for each of the deviations.
Table 2. Frequency and percentage for each type of scoliosis by location.

\begin{tabular}{c|c|c|c}
\hline Type of scoliosis & & Frequency & Percentage \\
\hline \multirow{2}{*}{ Right thoracolumbar } & No & 8 & $66.7 \%$ \\
\cline { 2 - 4 } & Yes & 4 & $33.3 \%$ \\
\hline \multirow{2}{*}{ Left thoracolumbar } & No & 6 & $50 \%$ \\
\cline { 2 - 4 } & Yes & 6 & $50 \%$ \\
\hline \multirow{2}{*}{ Right thoracic } & No & 9 & $75 \%$ \\
\cline { 2 - 4 } & Yes & 3 & $25 \%$ \\
\hline \multirow{2}{*}{ Left thoracic } & No & 12 & $100 \%$ \\
\cline { 2 - 4 } & Yes & 0 & $0 \%$ \\
\hline \multirow{2}{*}{ Right lumbar } & No & 12 & $100 \%$ \\
\cline { 2 - 4 } & Yes & 0 & $0 \%$ \\
\hline \multirow{2}{*}{ Left lumbar } & No & 11 & $91.7 \%$ \\
\cline { 2 - 4 } & Yes & 1 & $8.3 \%$ \\
\hline
\end{tabular}

No: absence of scoliosis; Yes: presence of scoliosis.

Table 3. Relationship between the average contraction in the presence of lateral imbalances ( $\mu$ Lat) of the right longissimus (RLT) and left longissimus (LLT) and right thoracolumbar scoliosis.

Right thoracolumbar scoliosis and response of the longissimus thoracis to the lateral imbalance

\begin{tabular}{|c|c|c|c|c|c|}
\hline & & & & \multicolumn{2}{|c|}{ LLT ( $\mu$ Lat) } \\
\hline \multicolumn{4}{|c|}{ Right thoracolumbar scoliosis } & $\begin{array}{c}\text { Insufficient } \\
\text { response }\end{array}$ & $\begin{array}{l}\text { Correct } \\
\text { response }\end{array}$ \\
\hline \multirow{4}{*}{ No } & \multirow{4}{*}{$\begin{array}{c}\mathrm{RLT} \\
(\mu \text { Lat })\end{array}$} & \multirow{2}{*}{$\begin{array}{l}\text { Insufficient } \\
\text { response }\end{array}$} & Count & 3 & 0 \\
\hline & & & $\%$ No scoliosis & $37.5 \%$ & $0 \%$ \\
\hline & & \multirow{2}{*}{$\begin{array}{l}\text { Correct } \\
\text { response }\end{array}$} & Count & 1 & 4 \\
\hline & & & $\%$ No scoliosis & $12.5 \%$ & $50 \%$ \\
\hline \multirow{4}{*}{ Yes } & \multirow{4}{*}{$\begin{array}{c}\mathrm{RLT} \\
(\mu \text { Lat })\end{array}$} & \multirow{2}{*}{$\begin{array}{l}\text { Insufficient } \\
\text { response }\end{array}$} & Count & 1 & 1 \\
\hline & & & $\%$ Yes scoliosis & $25 \%$ & $25 \%$ \\
\hline & & \multirow{2}{*}{$\begin{array}{l}\text { Correct } \\
\text { response }\end{array}$} & Count & 1 & 1 \\
\hline & & & $\%$ Yes scoliosis & $25 \%$ & $25 \%$ \\
\hline
\end{tabular}

Significance for "No scoliosis" $p=0.028 *$ *

No: absence of scoliosis; Yes: presence of scoliosis.

Thus, in the cases in which right thoracolumbar scoliosis did not exist, $37.5 \%(n=3)$ presented insufficient bilateral IC responses and $50 \%(n=4)$ presented correct bilateral IC responses.

In the cases with left thoracic and right lumbar scolioses, 50\% $(n=6)$ presented correct bilateral IC responses.

In the cases of left thoracolumbar scoliosis, $66.7 \%(n=4)$ presented correct responses for the right and left IC and 33.3\% $(n=2)$ insufficient bilateral responses.

In relation to anteroposterior imbalances for the LT (Table 5), we observed statistically significant differences for the absence of right thoracolumbar $(p=0.005)$, right thoracic $(p=0.018)$, left thoracic $(p=0.005)$, right lumbar $(p=0.005)$, and left lumbar $(p=0.007)$ scolioses, and for the presence of left thoracolumbar scoliosis $(p=0.014)$.

In this sense, for the absence of right thoracolumbar scoliosis, the responses of the LT muscles were divided between insufficient $(25 \%, n=2)$ and correct $(75 \%, n=6)$.

For the absence of right thoracic scoliosis, the responses of the right and left IC muscles were correct in $62.5 \%(n=5)$.

For cases where left thoracic and right lumbar scolioses were not observed, $66.7 \%(n=8)$ of the bilateral LT responses were correct.

In turn, a higher percentage $(63.6 \%, n=7)$ of cases with the absence of left lumbar scoliosis had correct bilateral LT responses.

Finally, among the cases of left thoracolumbar scoliosis, $66.7 \%$ $(n=4)$ presented correct right and left LT responses and 33.3\% $(n=2)$ had insufficient responses. 
Table 4. Association between the average contraction in the presence of anteroposterior imbalances ( $\mu \mathrm{AP})$ of the right lumbar iliocostalis $(\mathrm{RIC})$ and the left lumbar iliocostalis (LIC) and the type of scoliosis.

\begin{tabular}{|c|c|c|c|c|c|}
\hline \multicolumn{6}{|c|}{$\begin{array}{l}\text { Scoliosis and the response of the lumbar } \\
\text { iliocostalis to anteroposterior imbalance }\end{array}$} \\
\hline \multirow{2}{*}{\multicolumn{4}{|c|}{ Right thoracolumbar scoliosis }} & \multicolumn{2}{|c|}{ LIC $(\mu$ AP $)$} \\
\hline & & & & $\begin{array}{c}\text { Insufficient } \\
\text { response }\end{array}$ & $\begin{array}{c}\text { Correct } \\
\text { response }\end{array}$ \\
\hline \multirow{4}{*}{ No } & \multirow{4}{*}{$\begin{array}{l}\text { ICdrcho } \\
(\mu \mathrm{AP})\end{array}$} & \multirow{2}{*}{$\begin{array}{l}\text { Insufficient } \\
\text { response }\end{array}$} & Count & 3 & 0 \\
\hline & & & $\%$ No scoliosis & $37.5 \%$ & $0 \%$ \\
\hline & & \multirow{2}{*}{$\begin{array}{l}\text { Correct } \\
\text { response }\end{array}$} & Count & 1 & 4 \\
\hline & & & $\%$ No scoliosis & $12.5 \%$ & $50 \%$ \\
\hline \multicolumn{4}{|c|}{ Significance for "No scoliosis" $p=0.028^{* *}$} & & \\
\hline \multicolumn{4}{|c|}{ Escoliosis dorsolumbar izquierda } & & \\
\hline \multirow{4}{*}{ Yes } & \multirow{4}{*}{$\begin{array}{l}\text { ICdrcho } \\
(\mu \mathrm{AP})\end{array}$} & \multirow{2}{*}{$\begin{array}{l}\text { Insufficient } \\
\text { response }\end{array}$} & Count & 2 & 0 \\
\hline & & & $\%$ Yes scoliosis & $33.3 \%$ & $\%$ \\
\hline & & \multirow{2}{*}{$\begin{array}{l}\text { Correct } \\
\text { response }\end{array}$} & Count & 0 & 4 \\
\hline & & & $\%$ Yes scoliosis & $\%$ & $66.7 \%$ \\
\hline \multicolumn{6}{|c|}{ Significance for "Yes scoliosis" $p=0.014^{* *}$} \\
\hline \multicolumn{4}{|c|}{ Left thoracic scoliosis } & & \\
\hline \multirow{4}{*}{ No } & \multirow{4}{*}{$\begin{array}{r}\text { ICdrcho } \\
(\mu \mathrm{AP})\end{array}$} & \multirow{2}{*}{$\begin{array}{c}\text { Insufficient } \\
\text { response }\end{array}$} & Count & 3 & 0 \\
\hline & & & $\%$ No scoliosis & $25 \%$ & $0 \%$ \\
\hline & & \multirow{2}{*}{$\begin{array}{l}\text { Correct } \\
\text { response }\end{array}$} & Count & 3 & 6 \\
\hline & & & $\%$ No scoliosis & $25 \%$ & $50 \%$ \\
\hline \multicolumn{6}{|c|}{ Significance for "No scoliosis" $p=0.046 * *$} \\
\hline \multicolumn{4}{|c|}{ Right lumbar scoliosis } & & \\
\hline \multirow{4}{*}{ No } & \multirow{4}{*}{$\begin{array}{c}\mathrm{RIC} \\
(\mu \mathrm{AP})\end{array}$} & \multirow{2}{*}{$\begin{array}{l}\text { Insufficient } \\
\text { response }\end{array}$} & Count & 3 & 0 \\
\hline & & & $\%$ No scoliosis & $25 \%$ & $0 \%$ \\
\hline & & \multirow{2}{*}{$\begin{array}{l}\text { Correct } \\
\text { response }\end{array}$} & Count & 3 & 6 \\
\hline & & & $\%$ No scoliosis & $25 \%$ & $50 \%$ \\
\hline \multicolumn{4}{|c|}{ Significance for "No scoliosis" $p=0.046^{* *}$} & & \\
\hline
\end{tabular}

\section{DISCUSSION}

We found that $100 \%$ of the study population, all classified as GMFCS level V, had at least one curve greater than $10^{\circ}$ as measured by the Cobb method, in line with the authors who associate scoliosis with cerebral palsy and the motor level. ${ }^{5-6}$

In reference to the location of the scoliosis and the type of $\mathrm{CP}$, our data agrees with more global studies in which, both for patients with greater limitations on mobility ${ }^{7}$ and in spastic forms of cerebral palsy, the thoracolumbar tract is the most affected. ${ }^{6}$

As for the etiopathogenesis of scoliosis in $\mathrm{CP}$, our results do not present either muscle group as a direct cause of the spinal deviations, in accordance with reviews in which no significant correlation is found between muscle asymmetry and curvature as the origin or initial trigger. ${ }^{21}$

However, our study shows significant associations between the symmetrical responses in the presence of anteroposterior imbalances of the LT and IC and the absence of scoliosis. Although this symmetry refers to both insufficient and correct responses, we observed an important difference in favor of the correct ones.

So, for the iliocostalis lumborum, the correct responses exceeded the insufficient responses both for right thoracolumbar scoliosis (50\% versus $37.5 \%$ ) and for left thoracic and right lumbar scolioses (50\% versus $25 \%$ )

Similarly, for the longissimus thoracis in the presence of AP imbalances, correct responses exceeded insufficient responses (always bilaterally) in right thoracolumbar (75\% versus $25 \%$ ), right thoracic (62.5\% versus $37.5 \%$ ), left thoracic and right lumbar (66.7\% versus $25 \%$ ), and left lumbar (63.6\% versus $27.3 \%$ ) scolioses.

These data highlight the importance of symmetry in muscle responses as a factor in the prevention of spinal deviations and agree with Ferrari et al, ${ }^{6}$ who consider symmetric patterns as protectors of trunk
Table 5. Association between the average contraction in the presence of anteroposterior imbalances ( $\mu \mathrm{AP})$ of the right (RLT) and left (LLT) longissimus and the type of scoliosis.

\begin{tabular}{|c|c|c|c|c|c|}
\hline \multicolumn{6}{|c|}{$\begin{array}{l}\text { Scoliosis and the response of the longissimus to } \\
\text { anteroposterior imbalance }\end{array}$} \\
\hline \multirow{2}{*}{\multicolumn{4}{|c|}{ Right thoracolumbar scoliosis }} & \multicolumn{2}{|c|}{ LLT $(\mu$ AP) } \\
\hline & & & & \begin{tabular}{|c|} 
Insufficient \\
response
\end{tabular} & $\begin{array}{c}\text { Correct } \\
\text { response }\end{array}$ \\
\hline \multirow{4}{*}{ No } & \multirow{4}{*}{$\begin{array}{c}\text { RLT } \\
(\mu \mathrm{AP})\end{array}$} & \multirow{2}{*}{$\begin{array}{l}\text { Insufficient } \\
\text { response }\end{array}$} & Count & 2 & 0 \\
\hline & & & $\%$ No scoliosis & $25 \%$ & $0 \%$ \\
\hline & & \multirow{2}{*}{$\begin{array}{l}\text { Correct } \\
\text { response }\end{array}$} & Count & 0 & 6 \\
\hline & & & $\%$ No scoliosis & $0 \%$ & $75 \%$ \\
\hline \multicolumn{6}{|c|}{ Significance for "No scoliosis" $p=0.005^{* *}$} \\
\hline \multicolumn{6}{|c|}{ Left thoracolumbar scoliosis } \\
\hline \multirow{4}{*}{ Yes } & \multirow{4}{*}{$\begin{array}{l}\text { RLT } \\
(\mu \mathrm{AP})\end{array}$} & \multirow{2}{*}{$\begin{array}{l}\text { Insufficient } \\
\text { response }\end{array}$} & Count & 2 & 0 \\
\hline & & & $\%$ Yes scoliosis & $33.3 \%$ & $0 \%$ \\
\hline & & \multirow{2}{*}{$\begin{array}{c}\text { Correct } \\
\text { response }\end{array}$} & Count & 0 & 4 \\
\hline & & & $\%$ Yes scoliosis & $0 \%$ & $66.7 \%$ \\
\hline \multicolumn{6}{|c|}{ Significance for "Yes scoliosis" $p=0.014^{* *}$} \\
\hline \multicolumn{4}{|c|}{ Right thoracic scoliosis } & & \\
\hline \multirow{4}{*}{ No } & \multirow{4}{*}{$\begin{array}{l}\text { RLT } \\
(\mu \mathrm{AP})\end{array}$} & \multirow{2}{*}{$\begin{array}{l}\text { Insufficient } \\
\text { response }\end{array}$} & Count & 3 & 1 \\
\hline & & & $\%$ No scoliosis & $37.5 \%$ & $12,5 \%$ \\
\hline & & \multirow{2}{*}{$\begin{array}{l}\text { Correct } \\
\text { response }\end{array}$} & Count & 0 & 5 \\
\hline & & & $\%$ No scoliosis & $0 \%$ & $62.5 \%$ \\
\hline \multicolumn{6}{|c|}{ Significance for "No scoliosis" $p=0.018^{* *}$} \\
\hline \multicolumn{4}{|c|}{ Left thoracic scoliosis } & & \\
\hline \multirow{4}{*}{ No } & \multirow{4}{*}{$\begin{array}{l}\text { RLT } \\
(\mu \mathrm{AP})\end{array}$} & \multirow{2}{*}{$\begin{array}{l}\text { Insufficient } \\
\text { response }\end{array}$} & Count & 3 & 1 \\
\hline & & & $\%$ No scoliosis & $25 \%$ & $8.3 \%$ \\
\hline & & \multirow{2}{*}{$\begin{array}{l}\text { Correct } \\
\text { response }\end{array}$} & Count & 0 & 8 \\
\hline & & & $\%$ No scoliosis & $0 \%$ & $66.7 \%$ \\
\hline \multicolumn{6}{|c|}{ Significance for "No scoliosis" $p=0.005^{* *}$} \\
\hline \multicolumn{4}{|c|}{ Right lumbar scoliosis } & & \\
\hline & & Insufficient & Count & 3 & 1 \\
\hline $\mathrm{No}$ & RLT & response & $\%$ No scoliosis & $25 \%$ & $8.3 \%$ \\
\hline TNO & $(\mu \mathrm{AP})$ & Correct & Count & 0 & 8 \\
\hline & & response & $\%$ No scoliosis & $0 \%$ & $66.7 \%$ \\
\hline & nificance & or "No scolic & $s^{\prime \prime} p=0.005^{* *}$ & & \\
\hline & & $\mathrm{ft}$ lumbar scc & osis & & \\
\hline & & Insufficient & Count & 3 & 1 \\
\hline & RLT & response & $\%$ No scoliosis & $27.3 \%$ & $9.1 \%$ \\
\hline No & $(\mu \mathrm{AP})$ & Correct & Count & 0 & 7 \\
\hline & & response & $\%$ No scoliosis & $0 \%$ & $63.6 \%$ \\
\hline & ificance & r "No scolic & $s^{\prime \prime} p=0.007^{* *}$ & & \\
\hline
\end{tabular}

block maintenance, or Benitez-Feliponi, ${ }^{22}$ who recognizes symmetries of trunk mobility as one of the factors related to scolioses in $\mathrm{CP}$.

At the same time, they can be summed up as postural reflexes, since, in addition to symmetry, in cases where scoliosis does not appear, there is a higher percentage of correct responses that relate to balancing responses of the muscles. In this sense, authors like Vialle et al, ${ }^{23}$ who talk about spinal deformity induced by muscular incoordination and a lack of muscular compensation mechanisms, as well as the collapse of the trunk secondary to asymmetrical maintenance forces, or Imrie and Yaszay, ${ }^{24}$ who implicate imbalance of the trunk among other factors, are supported.

For all of the above and keeping in mind that significant associations were only noted for lateral imbalances on right thoracolumbar scoliosis, muscle responses at the anteroposterior level are those of greater specific weight.

This statement coincides with results of VCR and vestibular stimulation studies in $\mathrm{CP}$, in which significant changes have been verified at the anteroposterior level. ${ }^{10}$

Therefore, our study presents the search for symmetrical postural responses at the anteroposterior level as a possible tool against 
the development or structuring of scoliosis in patients with great limitation of mobility along the same lines as the objectives of other investigations of scoliosis in patients without neurological changes in which a reduction in the rates of asymmetry of the trunk musculature is also sought. ${ }^{25}$

However, in this case, treatment of orthopedic problems of the spine in this population is based on physical therapy of these postural responses.

All these statements would also be in accordance, from the point of view of the mechanomorphosis of the spine, with studies that discuss maintenance of asymmetrical vertebral loads as a facilitator of the structuring of spinal deviations. ${ }^{26}$

In contrast, despite all of the above, our data leave other causes and factors implicated in the development of scoliosis in CP open, since the symmetrical bilateral IC and LT responses in cases of left thoracolumbar locations were exceptions.

\section{CONCLUSIONS}

In our population, we did not observe the asymmetry of the IC and LT muscle responses to be the main cause of the appearance and development of scoliosis.

However, the symmetry of the responses seems to be one of the factors that prevent the appearance of spinal deviations in this population of patients with CP and GMFCS level V.

The main limitation of the study is the number of participants, which in spite of preventing extrapolation to other populations, does not contain a line to prevent the progress of musculoskeletal changes so harmful to this population.

All authors declare no potential conflict of interest related to this article.

CONTRIBUTION OF THE AUTHORS: Each author has contributed individually and significantly to the development of the manuscript. OAM (0000$0002-8871-239 X)^{\star}$, BFE (0000-0003-3780-7521)* and FZO (0000-0002-1189-894X)* have carried out the conception of the study. FZO, OAM and BPO $(0000-0001-5039-6101)^{\star}$ have designed the study. OAM, BFE and RMP (0000-0002-7843-1279)* have obtained the data. FZO, OAM, BFE, BPO and RMP have analyzed and interpreted the data. BPO and OAM have carried out the bibliographic search. OAM, FZO and BFE have drafted the manuscript. OAM, FZO, BFE, BPO and RMP have carried out a critical review of the work. OAM, FZO, BFE, BPO and RMP have approved the final version of the manuscript. *ORCID (Open Researcher and Contributor ID).

\section{REFERENCES}

1. KotwickiT, Szulc A. Curvature of the spine in children with cerebralpalsy. Ortop Traumatol. Rehabil. 2002;4(1):42-7.

2. Porter D, Michael S, Kirkwood C. Patterns of postural deformity in non-ambulant people with cerebral palsy: what is the relationship between the direction of scoliosis, direction of pelvic obliquity, direction of windswept hip deformity and side of hip dislocation?.Clinical Rehabil. 2007;21(12):1087-96.

3. Rodby-Bousquet E, Czuba T, Hägglund G, Westbom L. Postural asymmetries in young adults with cerebral palsy. Dev Med Child Neurol. 2013;55(11):1009-15.

4. Porter D, Michael S, Kirkwood C. Is there a relationship between preferred posture and positioning in early life and the direction of subsequent asymmetrical postural deformity in non ambulant people with cerebral palsy? Child Care Health Dev. 2008;34(5):635-41.

5. Zurita F, Alí O, Martínez R. Reacciones laberínticas de enderezamiento cervical y escoliosis en la parálisis cerebral. Rev Ped Elec. 2011;8(1):2-15.

6. Ferrari A, Ferrara C, Balugani M, Sassi S. Severe scoliosis in neurodevelopmental disabilities: clinical signs and therapeutic proposals. Eur J Phys Rehab Med. 2010; 46(4):563-80.

7. I Tsirikos A. Development and treatment of spinal deformity in patients with cerebral palsy. Indian J Orthop. 2010;44(2):148-58.

8. Domagalska-Szopa M, Szopa A. Body posture asymmetry differences between children with mild scoliosis and children with unilateral cerebral palsy. Biomed Res Int. 2013;462094.

9. Simoneau $M$, Lamothe $V$, Hutin $E$, Mercier $P$ Teasdale $N$, Blouin J Evidence for cognitive vestibular integration impairment in idiophatic scoliosis patients. BMC Neurosci. 2009;10:102

10. Ali-Morell OJ, Zurita-Ortega F, Martínez-Porcel R, Padilla-Obispo I. Reflejo vestibu locervical y función motora gruesa en una población con parálisis cerebral. Rehabilitación. 2014;48(1):39-45.

11. Palastanga N, Field D, Soames R. Anatomía y movimiento humano. Estructura y funcionamiento. Barcelona: Paidotribo; 2000; p.426-9.

12. Ali AS, Rowen KA, lles JF. Vestibular actions on back and lower limb muscles during postural tasks in man. J Physiol. 2003;546 (Pt 2): 615-24.

13. Palisano R, Rosenbaum P, Walter $S$, Rusell D, Wood E, Galuppi B. Development and reliability of a system to classify gross motor function in children with cerebral palsy. Dev Med Child Neurol.1997;39(4):214-23.
14. Yacizi M, Senaran H. Cerebral palsy and spinal deformities. Acta OrthopTraumatol Turc. 2009:43(2):149-55

15. Berker AN, Yalçin MS. Cerebral Palsy: orthopedic aspects and rehabilitation. Pediatr Clin North Am. 2008;55(5):1029-25.

16. Ali-Morell OJ, Zurita-Ortega F, Martínez-Porcel $R$, González-Astorga $E$, Cano-Mañas MJ. Registro de la actividad muscular en abductores y adductores en las alteraciones de cadera de los individuos con parálisis cerebral. Rehabilitacion 2013;47(1):35-43.

17. Hermens HJ, Freriks B, Disselhorst-Klug C, Rau G. Development of recommendations for SEMG sensors and sensor placement procedures. J Electromyogr Kinesiol. 2000; 10(5):361-74

18. Alvarez-Molinero M, Gálvez-Koslowski S, llopart-Alcalde N, Santos-Andrés JF, Aguilar-Naranjo JJ. Comparación de la medición del ángulo de Cobb: tradicional versus asistida por ordenador. Rehabilitación. 2011;45(2):93-8.

19. Lenke LG, Betz RR, Harms J, Bridwell KH, Clements DH, Lowe TG, et al. Adolescent idiopathic scoliosis: a new classification to determine extent of spinal arthrodesis. J Bone Joint Surg Am. 2001;83(8):1169-81.

20. Phan P, Mezghani N, Aubin CÉ, de Guise JA, Labelle H. Computer algorithms and applications used to assist the evaluation and treatment of adolescent idiopathic scoliosis: a review of published articles 2000-2009. Eur Spine J. 2011;20(7):1058-68.

21. Driscoll SW, Skinner J. Musculoskeletal complications of neuromuscular disease in children. Phys Med Rehabil Clin N AM. 2008:19(1):163-94.

22. Benítez-Feliponi A. Estudio de los antecedentes perinatales y del diagnóstico precoz de la parálisis cerebral infantil en recién nacidos de alto riesgo.[Tesis doctoral], Granada, Universidad de Granada, 2012

23. Vialle R, Thénenin-Lemoine $C$, Mary P. Neuromuscular scoliosis. Orthop Traumatol Surg Res. 2013;99 (1 Suppl): S 124-39.

24. Imrie MN, Yaszay B. Management of spinal deformity in cerebral palsy. Orthop Clin North Am. 2010:41(4):531-47.

25. Tecco S, Mummolo S, Marchetti E, Tetè S, Campanella V, Gatto R, et la. sEMG activity of masticatory, neck, and trunk muscles during the treatment of scoliosis with functional braces. A longitudinal controlled study. J Electromyogr Kinesiol. 2011; 21(6):885-92.

26. Hawes MC, O'brien JP. The transformation of spinal curvature into spinal deformity: pathological processes and implications for treatment. Scoliosis. 2006;1(1):3. 